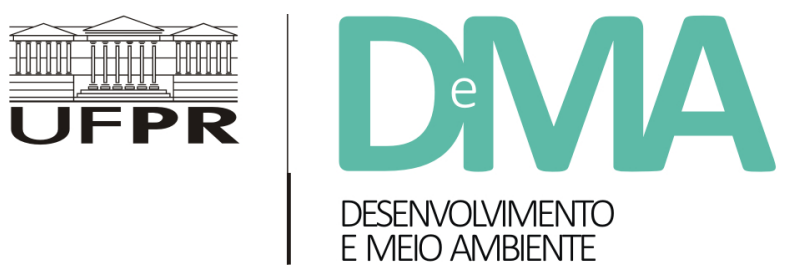

\title{
Problemas socioambientais decorrentes da urbanização e turismo: estudo de caso da Lagoa das Capivaras, Garopaba (SC), Brasil
}

\section{Socio-Environmental Problems Arising from Urbanization and Tourism: Lagoa das Capivaras, Garopaba (SC), Brazil Case Study}

\author{
Amanda Bellettini MUNARI ${ }^{*}$, Viviane Kraieski de ASSUNÇÃO ${ }^{1}$, Carlyle Torres Bezerra de MENEZES ${ }^{1}$ \\ ${ }^{1}$ Programa de Pós-Graduação em Ciências Ambientais (PPGCA), Universidade do Extremo Sul Catarinense (UNESC), Criciúma, SC, Brasil. \\ *E-mail de contato: amandabellettini@gmail.com
}

Artigo recebido em 31 de agosto de 2017, versão final aceita em 26 de novembro de 2017.

\begin{abstract}
RESUMO: Os municípios do litoral brasileiro vêm passando por um acelerado crescimento demográfico nas últimas décadas, acompanhado pela degradação dos ecossistemas costeiros. Este estudo objetivou compreender, por meio da memória de moradores de Garopaba, município litorâneo do Estado de Santa Catarina, as alterações ocorridas em duas lagoas localizadas no centro do município, a Lagoa das Capivaras e a Lagoa Pequena. Esta última foi aterrada para a implantação de um empreendimento imobiliário, enquanto a primeira está sofrendo um grave processo de degradação. A pesquisa, de natureza qualitativa, foi realizada por meio de entrevistas em profundidade com 25 moradores locais. Os resultados demonstram que as alterações sofridas nas lagoas e em seu entorno devem ser compreendidas paralelamente aos processos de urbanização e do crescimento acelerado do turismo de massa em Garopaba. Estes processos estão atrelados à construção de espaços para lazer para camadas média e alta e ao distanciamento dos habitantes locais destes espaços mais nobres do município. Diante deste contexto, faz-se necessária a implementação de programas de gerenciamento costeiro integrado e compartilhado com a comunidade local para minimizar os efeitos desta tendência evolutiva e recuperar as áreas afetadas, bem como a busca por novos modelos de desenvolvimento, com uma concepção ambiental e social para a zona costeira.
\end{abstract}

Palavras-chave: urbanização; turismo de massa; lagoas costeiras; memória.

ABSTRACT: The municipalities of the Brazilian coast have been experiencing an accelerated demographic growth in the last decades, followed by the destruction of the coastal ecosystems. This study aimed at 
understanding, through the memory of Garopaba residents, the changes occurred in two lagoons located in the center of the municipality, the Lagoa das Capivaras and Lagoa Pequena. The latter was grounded for the implementation of a real estate development, while the former is undergoing a serious process of degradation. The qualitative research was carried out through in-depth interviews with 25 local residents. The results demonstrate that the alterations suffered by the lagoons and their surroundings must be understood in parallel to the processes of urbanization and the growth of mass tourism in Garopaba. These processes are linked to the construction of spaces for leisure for middle and high classes and the distancing of the locals from these most noble spaces of the municipality. Given this context, it is necessary to implement integrated and shared coastal management programs with the local community, in order to minimize the effects of this evolutionary tendency and to recover the affected areas, as well as the search for new models of development, seeking an environmental and social conception for the coastal zone.

Keywords: urbanization; mass tourism; coastal lagoons; memory.

\section{Introdução}

A degradação dos ambientes costeiros, em função da intensa ocupação urbana e de ações antrópicas sem planejamento, tem acentuado o processo de destruição dos ecossistemas, que é agravado por sua capacidade restrita de suportar os impactos gerados por estas atividades. O município de Garopaba (localizado no litoral centro-sul do Estado de Santa Catarina, região sul do Brasil), assim como diversos municípios do litoral brasileiro, vem passando por um acelerado crescimento demográfico, bem como pela ausência de um planejamento do espaço costeiro (Asmus et al., 2006).

O aumento populacional e as pressões do setor imobiliário, sobretudo devido à implantação de empreendimentos no município que tinham como objetivo principal atender as demandas do turismo, acarretaram vários conflitos na região nos últimos anos (Araújo, 2008; Jacomel, 2012). A construção de empreendimentos privados afetou diretamente um ambiente antes preservado, ou ainda pouco impactado. Parte da Lagoa das Capivaras - a Lagoa Pequena, como conhecida localmente - foi aterrada para a implantação de um loteamento, que mais tarde foi embargado devido a uma Ação Civil Pública (Autos n ${ }^{\circ}$ 167.89.000056-0). Embora transcorridos quase 10 anos da condenação dos responsáveis para que eles procedessem à reparação dos danos ambientais, esta área ainda se encontra em estado de abandono e sem a adoção das medidas de recuperação ambiental, conforme preconizado na ação. Apesar da mobilização nos últimos anos de parte da comunidade local para a transformação dessa área em uma unidade de conservação, nos moldes de um parque ecológico municipal, tal proposição ainda não foi concretizada, e ainda vem sendo objeto de ações por parte dos gestores municipais, mas que estão sendo questionadas por atores organizados em movimentos ambientalistas locais (AMA, 2017; Garopaba, 2017).

A Lagoa das Capivaras está sendo degradada por estar situada em área urbanizada, entre o mar e o continente, recebendo o despejo de efluentes domésticos que está provocando a eutrofização da mesma, além do aterramento de suas margens, assoreamento e supressão de sua mata ciliar (Mariano, 2010). Recentemente, uma série de intervenções 
por parte dos gestores municipais efetuou ações de supressão da vegetação no entorno da lagoa e disposição de material de aterro nas suas margens, contribuindo com os processos de descaracterização e degradação da área no entorno da lagoa. As lagoas costeiras possuem grande importância ecológica, pois são responsáveis pela sobrevivência de muitas espécies aquáticas, como também pelo desenvolvimento da fauna e da flora que fazem parte de todo o ecossistema ali presente (Esteves, 2011). Além disso, proporcionam a manutenção do nível do lençol freático e o equilíbrio hidrológico local, contribuindo, também, para a estabilidade do clima no local, sendo fundamentais à produtividade biológica, mantendo a biodiversidade inerente ao ambiente em estudo (Kjerfve, 1994). A Lagoa das Capivaras enquadra-se nestes critérios de relevância socioecológica, justificando a preocupação quanto à adoção de medidas efetivas de conservação e restauração, conforme vem sendo evidenciado localmente nos últimos anos (Menezes \& Damásio, 2005; Mariano, 2010).

A partir desse contexto, a pesquisa procurou analisar, por meio da memória (Bosi, 1979; Halbwachs, 1990; Woortmann, 2000) de moradores de Garopaba, como estes sujeitos percebem as mudanças e/ou transformações socioespaciais ocorridas na lagoa nas últimas décadas. Os resultados possibilitaram a compreensão, a partir do ponto de vista dos moradores mais antigos do município, do histórico do processo de urbanização e dos impactos socioambientais causados pela expansão da atividade turística. Este processo de urbanização se deu em razão da apropriação de regiões do município de Garopaba como locais de segunda residência (Becker, 1995) por indivíduos de classes média e alta, que foi acompanhada por mudanças no modo de vida dos habitantes locais e em sua relação com o meio. Esta apropriação do espaço litorâneo está relacionada, em sua maioria, às transformações urbanísticas e espaciais decorrentes do crescimento e da modernização da zona costeira voltadas, em parte, para sujeitos que buscam viver em contato com a natureza (Wendel, 2005).

Estes ambientes demandam ações preventivas que valorizem a manutenção da paisagem e das riquezas da cultura local. Considerando todos estes aspectos, o Governo Federal instituiu, por meio da Lei $n^{\circ}$ 7.661/1988, o Plano Nacional de Gerenciamento Costeiro (PNGC), com base na Política Nacional de Meio Ambiente e na Política Nacional de Recursos do Mar (Ribeiro \& Coura, 2003). O gerenciamento costeiro constitui um conjunto de processos, ações e tomadas de decisões com a finalidade de priorizar o desenvolvimento sustentável nas zonas costeiras (Marroni \& Asmus, 2005). Deste modo, apresenta-se como um instrumento de planejamento territorial que, a partir da compreensão das formas desiguais de ocupação do litoral, pode contribuir na promoção de uma maior qualidade de vida para a população de maneira igualitária e participativa.

\section{Procedimentos metodológicos}

A pesquisa, inserida no âmbito da abordagem qualitativa (Bauer et al., 2008), foi realizada por meio de atividades de campo no município de Garopaba, localizado na região sul de Santa Catarina (Figura 1). O município possui uma área territorial de $115,405 \mathrm{~km}^{2}$ e uma população de aproximadamente 18.138 habitantes, com uma densidade demográfica de $157,17 \mathrm{hab} . / \mathrm{km}^{2}$ e estimativa de 20.545 habitantes para 2014 (IBGE, 2010). 

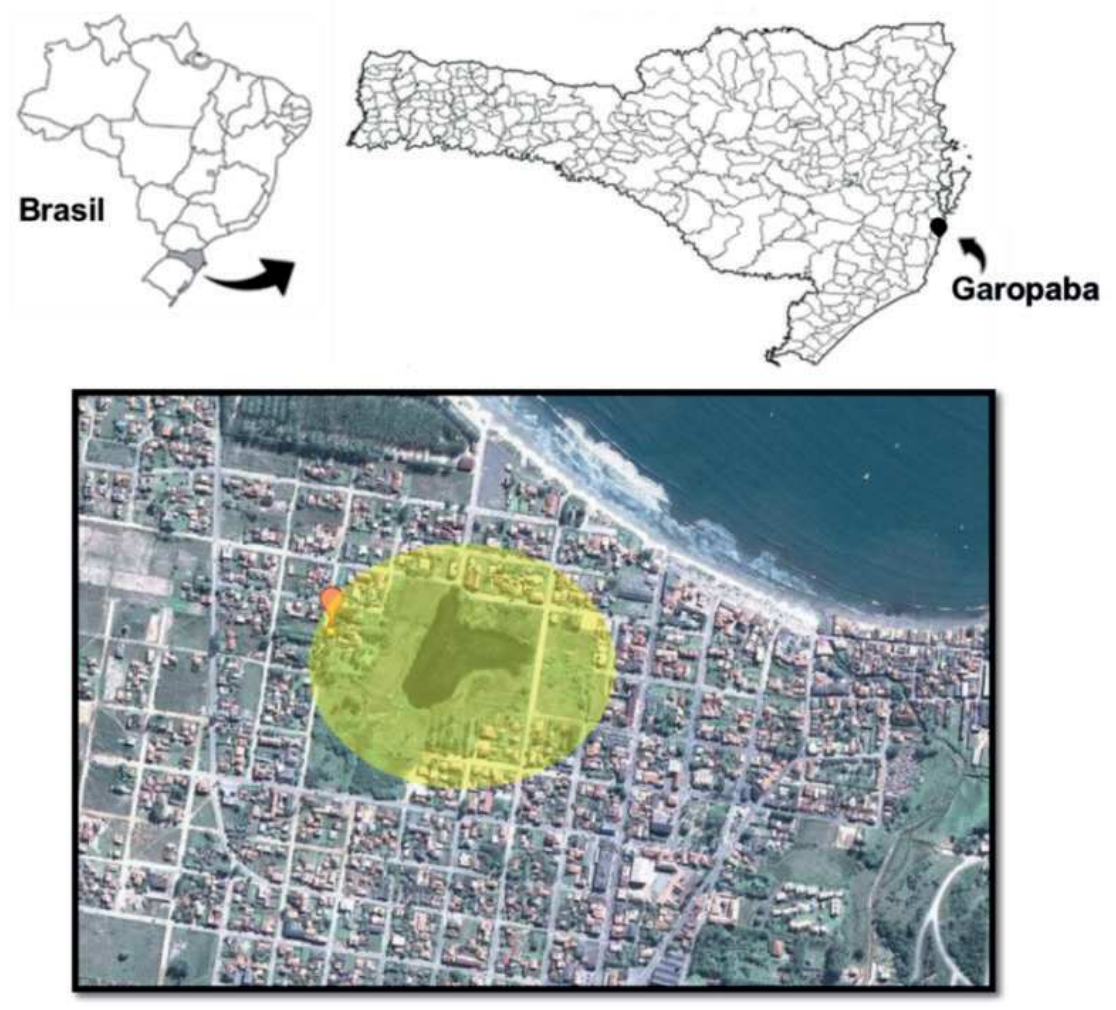

FIGURA 1 - Localização do município de Garopaba. Em destaque na imagem, a Lagoa das Capivaras (área em amarelo). FONTE: Google, 2017.

Durante o trabalho de campo, foram realizadas entrevistas em profundidade (Gaskell, 2008) com moradores de Garopaba que cumpriam os seguintes critérios: possuíam mais de 18 anos de idade, moravam em Garopaba há, pelo menos, dez anos, e declaravam conhecer a Lagoa das Capivaras e seu entorno e, portanto, poderiam discorrer sobre as alterações ocorridas no local nos últimos anos. Para a realização das entrevistas, foi utilizada a amostragem por Bola de Neve, na qual um informante-chave, identificado pelos pesquisadores, indica outro sujeito para incluir na amostra, acessan- do suas redes pessoais (Vinuto, 2014). Estas redes foram úteis, principalmente, para entrar em contato com sujeitos que moraram no entorno da Lagoa das Capivaras durante décadas e, posteriormente, mudaram-se para bairros mais distantes do centro do município. A busca por novos entrevistados foi interrompida após a realização de 25 entrevistas, quando os pesquisadores perceberam ter atingido o "ponto de saturação de sentido", ou seja, quando há indícios de que futuras entrevistas não apresentarão novos dados ou novas percepções (Gaskell, 2008). 
A maioria dos entrevistados já vivia há mais de 25 anos em Garopaba, sendo moradores nascidos no município ou pessoas que iniciaram a veranear na cidade e, posteriormente, firmaram residência. Os entrevistados possuem idade entre 35 e 88 anos, tendo ocupações diversas, tais como: pescadores, comerciantes, taxistas, aposentados ou que obtêm renda por meio do aluguel de casas para veraneio.

O roteiro de entrevista foi composto por questões voltadas à compreensão da percepção dos sujeitos da pesquisa sobre as mudanças socioespaciais ocorridas na Lagoa das Capivaras e no seu entorno nas últimas décadas. Os entrevistados foram indagados sobre as relações que estabeleceram com a lagoa ao longo dos anos, além de seu conhecimento e posicionamento sobre o aterramento da Lagoa Pequena.

Seguindo as concepções de Halbwachs (1990, p. 54), a memória é aqui considerada de forma individual e coletiva, que possui dimensões sociais. A memória não configura apenas uma lembrança, mas também uma espécie de ação, que pode ter caráter transformador na vida dos indivíduos (Bosi, 1979). Neste sentido, a memória elabora aquilo que foi vivido, mas também participa da construção do presente e do futuro. De acordo com Woortmann (2000, p. 213), "a memória opera no sentido de trabalhar o passado para forjar o presente e construir o futuro, e isto pode ser feito tanto pela rememoração como pelo esquecimento". A memória é seletiva e presentifica determinados acontecimentos, cujos significados estão associados a determinados contextos (Woortmann, 2000).

Todos os entrevistados assinaram o Termo de Consentimento Livre e Esclarecido apresentado na ocasião da entrevista, conforme a Resolução $n^{\circ}$ 466/2012 do Conselho Nacional de Saúde (Brasil,
2012), com Certificado de Apresentação para Apreciação Ética (CAAE: 54277116.1.0000.0119). Como forma de preservar o anonimato dos participantes da pesquisa, estes são identificados neste artigo apenas com as iniciais de seus nomes e suas idades.

As entrevistas foram integralmente transcritas e seus trechos foram classificados de acordo com temáticas, seguindo a análise e a interpretação de sentidos propostas por Gomes (2000). Os trechos classificados, bem como comentários e observações feitos pela pesquisadora durante a pesquisa de campo, serviram de ponto-chave não apenas para interpretar a percepção ambiental (Tuan, 1980) dos moradores sobre as situações anterior e atual da lagoa, como também as transformações socioambientais ocorridas no município de Garopaba de forma mais ampla, revelando que estas alterações deveriam ser relacionadas à urbanização e ao crescimento do turismo no município.

Além das entrevistas, foram realizadas conversas informais com os moradores de Garopaba possibilitadas pela vivência dos pesquisadores no município. Esta vivência foi importante para a compreensão do cotidiano e do modo de vida de seus habitantes, bem como para entender melhor a dinâmica urbana durante o período de veraneio (de dezembro a fevereiro) e nos demais meses do ano. Cabe salientar que, durante o trabalho de campo, foi possível presenciar algumas atividades realizadas no entorno da lagoa, como a presença de grupos indígenas durante o verão, queimadas e cortes de árvores, além de atividades relacionadas à construção civil. Os registros desta vivência foram feitos em diário de campo (Vieira, 2001) e, juntamente com a pesquisa bibliográfica e as entrevistas com moradores, contribuíram para o delineamento e a análise dos dados da pesquisa. 


\section{O processo de ocupação e transformação socioespacial no entorno da lagoa}

O primeiro povoamento de Garopaba ocorreu no ano de 1666 por imigrantes açorianos, que marcaram de modo particular o ambiente. Até este período, a região era ocupada por Guaranis, grupo indígena que habita o litoral catarinense e forma sociedades organizadas e inteiramente adaptadas ao ambiente (Santos, 2004) ${ }^{1}$. O modo de vida dos primeiros colonizadores, associado à influência da presença indígena, continua presente na exploração agrícola, em especial, a produção de farinha e de outros produtos derivados da cana-de-açúcar. Além disso, havia, já no início da colonização, embarcações voltadas à atividade pesqueira e, principalmente, à armação baleeira, com a caça de baleias e a comercialização de seu óleo e barbatanas, não mais presente no município desde o século XIX (Comerlato, 2011).

A primeira vila de Garopaba foi criada em 1877. A população vivia em torno do local onde atualmente é o Centro Histórico, com poucas casas espalhadas pela comunidade. A pesca, a agricultura familiar e os engenhos de farinha eram as principais atividades econômicas. As estradas de acesso eram precárias e sem pavimentação (Cerdan et al., 2011).

Em dezembro de 1961, Garopaba tornou-se oficialmente município. Desde a construção da rodovia BR-101, na década de 1970, e da SC-434, principal acesso ao município, intensificou-se a taxa de urbanização e ocorreu o incremento das atividades do setor terciário em detrimento das atividades primárias. Essas obras de pavimentação contribuíram para que muitas famílias de agricultores e pescadores passassem a realizar outras atividades remuneradas fora da agricultura e da pesca, que passaram a ser consideradas atividades econômicas complementares (Santin, 2005; Filardi, 2007; Guilardi, 2014). Neste processo, ainda em transição, os terrenos agrícolas foram dando lugar a novos loteamentos e a vários tipos de estabelecimentos comerciais voltados para o atendimento das demandas proporcionadas pelas atividades turísticas (Cerdan et al., 2011; Jacomel, 2012).

A ocupação urbana de Garopaba se deu, inicialmente, ao longo da orla da Praia Central e, posteriormente, no sentido praia-continente. Segundo um dos entrevistados, aproximadamente em 1970, Garopaba ainda era uma pequena vila. Em grande parte, era habitada por pescadores e sua praia era frequentada por um pequeno número de turistas. Praticamente não existia nenhuma infraestrutura para os visitantes, como estradas, restaurantes, hotéis etc. A Figura 2 ilustra a ocupação espacial, no início da década de 1970, da área atualmente denominada de "centro histórico" do município, onde é possível observar que havia poucas construções naquele período, e próximas à praia ficavam as moradias simples de pescadores locais.

$\mathrm{Na}$ área central de Garopaba, existiam duas lagoas, uma ao lado da outra, a Lagoa Pequena e a Lagoa das Capivaras (Figura 3). Atualmente, a Lagoa Pequena já não existe mais, pois foi aterrada no ano de 1988 com ações de abertura e pavimentação de vias. Essas ações contribuíram para que fossem ultrapassados os limites da antiga lagoa, ocasionando a descaracterização do antigo

${ }^{1}$ O nome Garopaba tem origem Guarani, e significa “enseada de barcos”, "lugar do descanso" ou ainda "lugar abençoado". Na língua Guarani, ygá, ygara, ygarata significam arco, embarcação, canoa, e mpaba paba tem por significado estância, lugar, enseada. 
ecossistema aquático. $\mathrm{O}$ aterramento seu deu para implantação de um empreendimento privado, fato este que motivou uma Ação Civil Pública (Autos $\mathrm{n}^{\circ}$ 167.89.000056-0) em decorrência do dano ambiental causado. Ações de degradação ambiental no ecossistema aquático ainda reincidiram em 1989, motivando o auto de infração. Este aterramento foi um dos motivos do processo judicial e da posterior condenação dos réus para a reparação dos danos ambientais. Não obstante tal condenação dos réus e a liquidação de sentença, ocorrida no ano 2008, até o momento os responsáveis ainda não tomaram as medidas necessárias para a reparação dos danos causados.
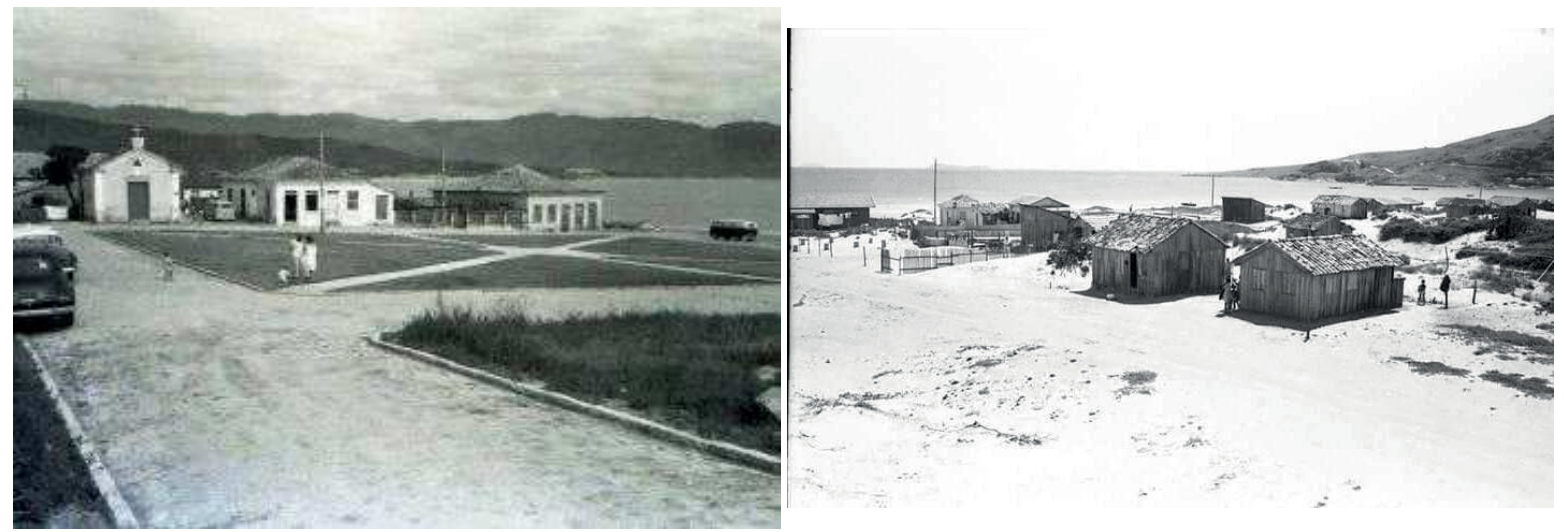

FIGURA 2 - Município de Garopaba, aproximadamente em 1970. FONTE: Fotos de Hübner, 2017.

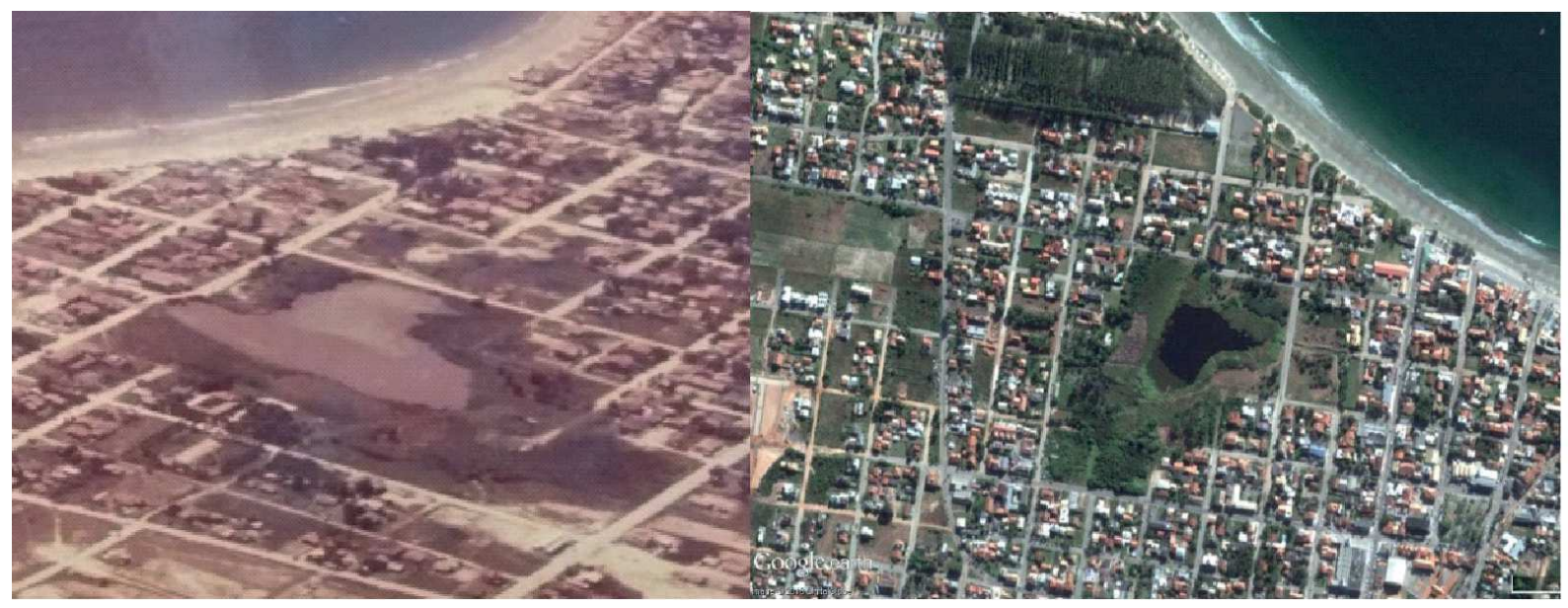

FIGURA 3 - Entorno da Lagoa das Capivaras (em verde) e da Lagoa Pequena (em amarelo) na década de 1970 e nos dias atuais. FONTE: Foto de Silva, 2017 e Google Maps, 2016. 
A lagoa das Capivaras continua sendo degradada por meio da construção de obras, tais como o calçamento da rua Dr. Elmo Kinceski, que passa entre o meio da Lagoa das Capivaras e antiga Lagoa Pequena, além da falta de coleta de lixo, que por vezes é depositado no local, e da ausência de instalações adequadas de saneamento básico nas residências e nos estabelecimentos comerciais no entorno da lagoa. Os sujeitos da pesquisa reconhecem que o aterramento da lagoa foi motivado por iniciativas de empresários da área da construção civil, com forte influência política e econômica no município.

A lagoa das Capivaras é um caso muito sério, vixi... ali tem muita encrenca, muito peixe grande [...] ali todo mundo quer, né, eles queria construir ali, os grandão aqui de Garopaba queriam construir ali, mas não deu certo porque fizeram coisa errada... eles tamparam a lagoa de cá, né (MRO, 56).

Aterraram a lagoa pra construir, né, aterraram... tão construindo casa e agora tá um matagal, tem um pedaço que têm, mas tá aterrado, construíram casas em volta, foram aterrando e agora é só de um (JGS, 42).

O espaço, constituído por sistemas de objetos e ações (Santos, 1999), não é apenas o lócus das mudanças ocorridas ao longo do tempo, pois também contribui para transformações das dinâmicas sociais, culturais e econômicas, como é possível observar nos relatos dos sujeitos da pesquisa. Segundo os entrevistados, há três décadas, era comum ver mulheres lavando roupas e homens pescando na lagoa. A atividade da pesca entrou em declínio após a diminuição dos peixes no local, pela contaminação da água por esgoto, em razão da ocupação intensa e sem planejamento do entorno da lagoa.

A Lagoa das Capivara tá cada vez mais crítica, antes eu pescava, pegava peixe, hoje não passo mais nem... não tenho coragem nem de molhar meus pé lá, tenho até medo, que antes eu tomava banho, mergulhava, brincava, a gente fazia jangada, andava de um lado para outro, nadava, mergulhava... hoje não deu mais (CRP, 54).

Eu nasci aqui na beira da lagoa, fui criado aqui, pescava e brincava e agora não dá mais, né, tá destruida mesmo (DBV, 55).

Ali tinham duas lagoa, né, a lagoa das capivaras, que era maior, e se pescava, e a lagoa pequena, que era mais para lavar roupa... as duas lagoa era boa e saudável, água limpa, limpinha, guria, uma era mais funda... nós andava até de barco e a pequena mais rasa que era pra lava roupa, que nós dizia que era a lagoa pequena (RFG, 62).

De acordo com os moradores, a atividade de construção civil está em alta na região, principalmente nas áreas próximas à praia. São visíveis as construções de casas, o que gera um aumento na demanda por mão de obra. Por este motivo, parte dos moradores nascidos em Garopaba deixou de lado a atividade de pesca e começou a trabalhar na construção civil, além de outras atividades relacionadas ao setor turístico.

Garopaba vivia da pesca e da lavoura. Hoje é diferente, vive de turismo, mudou, entendeu? Pessoal que trabalhava na lavoura saiu para trabalhar, pra vir trabalhar em Garopaba na construção civil, hotelaria, assim por diante, né, através do turismo (GGS, 47).

Os entrevistados compreendem que a lagoa está diminuindo de tamanho devido a plantas aquáticas que estão nascendo em grande quantidade em seu entorno, como pode ser observado na Figura 4. A reprodução destas plantas e seu alastramento são facilitados pela contaminação da água pelo 
despejamento de esgoto, que acarreta um processo de eutrofização (Menezes \& Damásio, 2005).

$\mathrm{Na}$ lagoa, existiam capivaras que também se constituíam em uma fonte alimentar para os moradores, além dos peixes. De acordo com a maioria dos entrevistados, a Lagoa das Capivaras é assim denominada devido à presença desses animais em suas proximidades. A ausência destes e outros animais atualmente na localidade revela que houve, nas últimas décadas, grandes transformações na paisagem (Pereira \& Eston, 2007). Um dos sujeitos da pesquisa relatou que, antes de a lagoa sofrer com o processo de urbanização, ao seu redor existiam dunas fazendo uma ligação com a praia e chegavam até as encostas do morro, iniciando a floresta, referindo-se, neste caso, ao Parque Estadual da Serra do Tabuleiro, no qual se faz presente a floresta ombrófila mista (floresta com araucárias) ${ }^{2}$. A vegetação foi desaparecendo aos poucos com a construção de moradias para turistas. As dunas foram lentamente sendo aplainadas, removidas e sua areia foi utilizada, em parte, na construção civil. Em relação à vegetação, os entrevistados contam que havia grande área verde no entorno da lagoa: "Era bem arborizada, linda, linda... nós andava de barco debaixo das árvores... [a lagoa] era bem arborizada mesmo, com bastante árvore" (PRV, 49). De acordo com os sujeitos da pesquisa, a área verde era composta por árvores frutíferas, como araçá (Psidium cattleyanum) e goiabeira (Psidium guajava), além de xaxim (Dicksonia sellowiana) e outras espécies que foram posteriormente cortadas para construção das residências. Alguns entrevistados afirmaram que

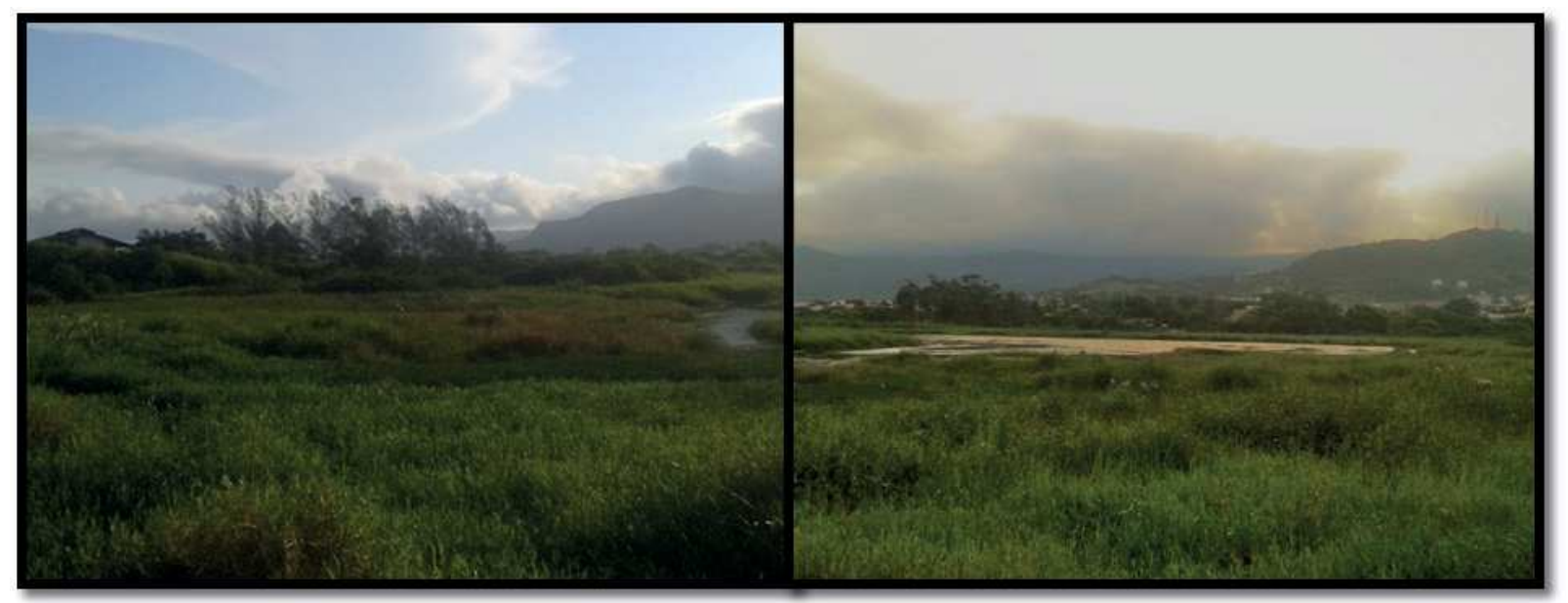

FIGURA 4 - Plantas no entorno e sobre da Lagoa

FONTE: Fotos de Munari, 2016.

${ }^{2}$ O parque, criado em 1975, abrangia a área de nove municípios, incluindo Garopaba. Em 2009, houve a recategorização de sua área, transformando o parque em um mosaico de unidades de conservação, com regimes jurídicos diferenciados (Reis, 2012). 
tinham o hábito de plantar árvores frutíferas e ervas medicinais no entorno da lagoa.

As entrevistas revelaram que, com o processo de urbanização e a vinda de mais pessoas para Garopaba, $\mathrm{o}$ aluguel de casas passou a ser uma nova fonte de renda para os moradores antigos, que deixaram as atividades de pesca e lavação de roupas, entre outras. Os entrevistados relataram que percebiam a lagoa como uma extensão de suas casas, onde realizavam diversas atividades.

É importante destacar que a lagoa constituía não apenas um local de trabalho para as lavadeiras, como também de sociabilidade (Simmel, 2006). Ex-lavadeiras mencionaram, durante as entrevistas, que a lagoa era um espaço onde podiam conversar sobre assuntos considerados proibidos em suas casas, tornando possível tratar de confidências sobre a intimidade familiar. Neste encontro, também ocorriam trocas de experiências e saberes entre mulheres, como o uso de plantas para fins medicinais. A lagoa era também um espaço de aprendizado para as crianças. Durante o trabalho, as mães levavam seus filhos à lagoa, que, além de nadar e brincar, também aprendiam ali seus futuros ofícios: os meninos, a pesca; as meninas, a lavação de roupas.

Existem diferentes formas de ocupação de espaço, sendo a apropriação (Neto, 2016) composta por lugares transitórios, como é o caso dos turistas que alugam as casas e que não constroem, necessariamente, uma relação de maior intensidade com o local ou um significado específico, pois lá permanecem por um curto período (Souza et al., 2013). Já para os moradores mais antigos ouvidos por esta pesquisa, existe a apropriação de um espaço essencial (Santos, 1999), com o qual foram estabelecidos um vínculo e uma relação de maior intensidade. Pode-se afirmar que a lagoa se tornou um prolongamento de suas casas (Jerônimo \& Gonçalves, 2013), articulando os espaços público e privado (Scarpeline, 2012). Percebe-se que há, por parte dos moradores mais antigos, uma manifestação de sentimentos de pertencimento pelo lugar onde moraram durante anos. Além de estar relacionado ao passado histórico destes sujeitos (Tuan, 1980), este sentimento de pertença constitui a identidade de grupos sociais que usam o território como base material e simbólica do "exercício da vida" (Santos, 2007, p. 22). Neste sentido, a memória coletiva favorece a manutenção das comunidades por constituir um componente de conexão, que assegura a construção e a continuidade de um futuro (Santos, 2001).

\section{Crescimento urbano e processos de exclusão}

Os relatos dos sujeitos da pesquisa sobre as transformações ocorridas na Lagoa das Capivaras e em seu entorno apontaram, paralelamente, transformações mais amplas do município, que estão atreladas à construção de uma paisagem urbana. Estas mudanças alteraram não apenas o ambiente natural, como também levaram a uma reconfiguração socioespacial e econômica de Garopaba, principalmente de suas áreas centrais.

Atualmente, Garopaba é um dos balneários mais procurados por turistas na região sul do Brasil, atraindo, além de visitantes nacionais, também uma grande quantidade de turistas vindos de países vizinhos, tais como Argentina e Uruguai, o que contribui para a ocupação intensa na orla em todo o período de verão. Assim como nos demais municípios litorâneos, sua urbanização vem ocorrendo 
com a turistificação (Sampaio, 2003; Rodrigues, 2015). Os fenômenos de veraneio (Matos \& Gruber, 2012) e de segunda residência (Becker, 1995) têm impactado fortemente o desenvolvimento dos assentamentos urbanos no litoral, estimulando a especulação imobiliária (Kohara et al., 2012). De acordo com relatos dos sujeitos da pesquisa, o turismo em Garopaba teve um crescimento significativo por volta da década de 1990, quando um pequeno número de indivíduos passou a veranear na área próxima à praia e no entorno da Lagoa das Capivaras, e, aos poucos, foi ocupando outras áreas do município e fixando sua segunda residência. Indivíduos, principalmente de classes média e alta, adquiriram lotes existentes próximos à orla marítima, onde posteriormente foram construindo casas e condomínios fechados para período de veraneio. $\mathrm{O}$ impacto deste aumento populacional nos meses de verão (de dezembro a fevereiro) pode ser observado nos números apresentados na Tabela 1. Destaca-se que, no período de veraneio, tem-se um aumento de $92 \%$ da densidade populacional no município de Garopaba.

TABELA 1 - População fixa e população flutuante (nos meses de verão)

\begin{tabular}{ll}
\hline \multicolumn{2}{c}{ GAROPABA } \\
\hline População (2010) & $18.138^{*}$ \\
População Estimada (2016) & $21.573^{*}$ \\
Área $\left(\mathrm{km}^{2}\right)$ & $115,405^{*}$ \\
Densidade Populacional $\left(\mathrm{hab} . / \mathrm{km}^{2}\right)-(2010)$ & $157,17 *$ \\
População Flutuante & $100.000^{* *}$ \\
Densidade Populacional Flutuante $\left(\mathrm{hab} / \mathrm{km}^{2}\right)$ & $866,52 * * *$ \\
\hline
\end{tabular}

FONTE: IBGE, 2010*; Garopaba, 2016**.

Dado calculado pelos pesquisadores, por meio da razão entre a população flutuante (Garopaba, 2016) e a área do município (IBGE, 2010).***
Com o aumento do turismo e sua consolidação como atividade econômica preponderante no município, a especulação imobiliária aumentou, seguida de um intenso processo de ocupação irregular - inclusive com indicativos de uma grande tendência de favelização nas áreas periféricas nos próximos anos (Jacomel, 2012; Pires, 2016). Este processo de crescimento urbano em áreas periféricas foi acompanhado por um processo de elitização dos espaços centrais do município, resultantes de políticas equivocadas de valorização seletiva de espaços urbanos (Santos, 1993) que acentuam a segregação espacial entre centro e periferia (Lojkine, 1997).

Este crescimento urbano se deu, em parte, em razão da apropriação de regiões do município de Garopaba como local de segunda residência. A aquisição de uma segunda residência é um fenômeno comum no litoral brasileiro, que foi marcado pela valorização da área costeira como paisagem de consumo, tornando-se um segmento voltado para as classes média e alta (Silva \& Fonseca, 2010). Este fenômeno turístico se expandiu no Brasil a partir da década de 1950, aliado ao desenvolvimentismo, com a construção de extensa malha viária ligando o interior ao litoral brasileiro e a instalação de empresas multinacionais do setor automobilístico. Também foi acompanhado pela emergência de classes médias urbanas com novos hábitos de consumo e valores associados ao turismo e ao lazer (Becker, 1995, p. 10). Este processo de ocupação da orla no litoral está atrelado ao "enobrecimento" das águas salgadas do mar e das faixas de praia da costa brasileira (Araújo, 2013) e relacionado às transformações urbanísticas decorrentes do crescimento e da modernização da zona costeira para classes de maior poder aquisitivo. 
Nesse sentido, a urbanização de Garopaba pode ser relacionada a uma "construção social da praia" para classes média e alta (Machado, 2000), transformando a natureza em áreas privadas, de acesso restrito para as classes menos abastadas (Wendel, 2005). Este processo de urbanização da cidade não está associado aos costumes e às tradições dos moradores mais antigos, mas à criação de novos espaços para indivíduos e grupos que buscam uma vida próxima à natureza (Wendel, 2005).

O espaço, antes frequentado majoritariamente por moradores locais, é pressionado pelo mercado imobiliário, fortalecendo ainda mais os processos de inclusão e exclusão de determinados grupos sociais (Santos, 1993). Atualmente, ainda existem apenas três moradores nascidos em Garopaba que residem no entorno da lagoa. Como explicou um dos moradores entrevistados, "como a lagoa era bonita, todo mundo queria morar ali, então o pessoal que tinha terreno foi vendendo aos poucos". Segundo os sujeitos da pesquisa, a venda destas casas se deu pela oferta de empreendedores com a valorização financeira da área, acompanhada da crescente necessidade dos moradores mais antigos, que viam a pesca como uma atividade instável e em declínio, devido aos arrastões ${ }^{3}$ e ao avanço da pesca industrial no município. A pesquisa identificou que os moradores que venderam seus terrenos migraram para bairros mais afastados do centro do município, tais como Ambrósio, Macacu, Campo d'Uma e Pinguirito, formando, consequentemente, um novo conjunto de relações sociais. Estes bairros encontram-se mais distantes da lagoa e não possuem a mesma infraestrutura do centro da cidade, fazendo com que muitos moradores se desloquem para trabalhar no centro da cidade todos os dias. A rápida urbanização, neste contexto, torna mais notórias as desigualdades econômicas e sociais nos entornos urbanos (Un-Habitat's', 2016).

Esta mudança dos moradores mais antigos para outras áreas é seguida por um processo de transformações e investimentos no centro do município, tanto nas moradias, que são renovadas ou reabilitadas, quanto na instalação de equipamentos e serviços na área no geral (Bataller, 2012). Atualmente, o entorno da Lagoa das Capivaras é ocupado por casas de alto padrão. Os três moradores locais que permanecem no entorno reformaram e/ou construíram novas casas neste mesmo padrão, as quais são alugadas em período de veraneio.

Este processo de mudanças físicas, sociais e econômicas pode ser denominado de gentrificação (Hamnett, 1991), fenômeno que se caracteriza pela ocupação de determinadas áreas urbanas por pessoas com elevada remuneração, que, paralelamente, acaba por afastar moradores locais com menor poder aquisitivo (Smith, 2007; Cerqueira, 2014). Este processo de elitização insere os espaços em novas lógicas de crescimento (Bidou-Zachariasen, 2006) e se desdobra na criação e na promoção de espaços artificiais com qualidade de vida em contato com a natureza, voltados a um público mais abastado, com valores distintos da vida da comunidade local (Silva, 2008).

Estas mudanças são visíveis no entorno da Lagoa das Capivaras, onde houve a construção de uma rua, bem como o aumento de empreendimentos comerciais e demais serviços destinados a atender

\footnotetext{
${ }^{3}$ Arrastão é uma modalidade de pesca na qual são utilizadas extensas redes, que são arrastadas ao longo do fundo do mar, removendo e destruindo diversas espécies marinhas.
} 
os veranistas e novos moradores. Este é um processo ainda em andamento em demais áreas do município de Garopaba. Anúncios de imobiliárias e construtoras apresentam a construção de infraestrutura para ocupação de classes média e alta em locais antes preservados, como se pode observar na Figura 5. No texto, é possível observar a menção à construção de uma estrada em parceria com a prefeitura do município, o que revela a convergência entre poder econômico e poder político.

Estas mudanças estão atreladas a fortes transformações econômicas do município. Guilardi (2014), retomando uma pesquisa realizada por Manoel Valentim, em 1961, revela que, naquele período, o município possuía os seguintes empreendimentos comerciais:

[...] duas lojas de fazenda e armarinho; quatro marcenarias; quatro serrarias; oitenta e seis engenhos de açúcar; dezenove vendas de secos e molhados; oito engenhos de farinha de mandioca, movidos a água; 297 engenhos de farinha de mandioca, movidos a boi; um engenho de farinha de mandioca, movido a motor e uma salga de pescado (Guilardi, 2014, p. 122).

Até a década de 1960, havia um predomínio de uma população rural, ligada à produção artesanal, com forte influência da colonização açoriana, como demonstram os dados acima. Este quadro

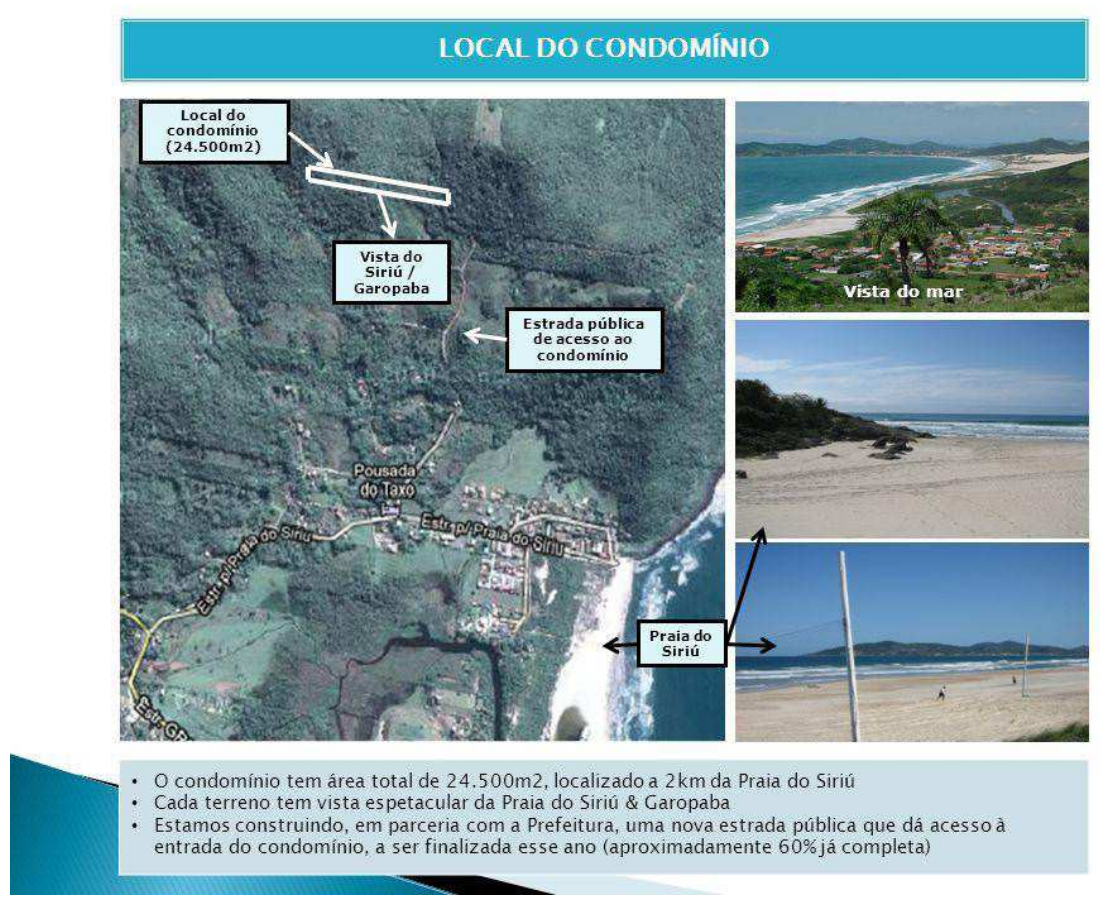

FIGURA 5 - Anúncio de condomínio construído no município de Garopaba. FONTE: Google, 2017. 
modifica-se drasticamente a partir da década de 1990. Guilardi (2014), que analisou a evolução do Produto Interno Bruto - PIB - no município entre 1999 e 2011, aponta que, neste período, o setor de serviços passou a contribuir para a maior parte do PIB local, com crescimento de 5,23 vezes. No mesmo período, a indústria também aumentou sua participação, com aumento de 7,82 vezes, enquanto as atividades agropecuárias perderam espaço na economia local, reduzindo sua participação de 7,57\% em 1999 para 4,14\% em 2011.

A partir da década de 1990, o processo de turistificação do município pode ser evidenciado pelo número crescente de empreendimentos de serviços voltados aos turistas. $\mathrm{Na}$ Tabela 2, são indicados os números de abertura de estabelecimentos dos setores de Alojamento e Alimentação, Imobiliário e Construção Civil, nos períodos 1990 a 1995 e 1996 e 2000, com dados de Guilardi (2014).

De acordo com a Prefeitura Municipal de Garopaba (PMG), no ano de 2013 estavam registrados 150 estabelecimentos do ramo de alimentação, bares e restaurantes; 120 empreendimentos classificados como supermercados, padarias e quitandas; 99 empresas do ramo da construção civil; 29 empreendimentos entre corretores, administradores de imóveis e loteadores, e incorporadores de atividades imobiliárias; 25 estabelecimentos relacionados às atividades de hospedagem, serviços de hotelaria e de pousada (Guilardi, 2014).

Nas últimas décadas, diversas áreas centrais urbanas, que continuamente eram objeto de ações de valorização, foram reinventadas como lugar de residência moderna, consumo e lazer de classes superiores (Cerqueira, 2014), como é o caso do entorno da lagoa. Atualmente, o entorno da lagoa configura-se como uma área com infraestrutura para atender a demanda de turistas e veranistas atraídos por propagandas de residências em loteamentos seguros e com qualidade de vida ao lado da natureza.

\section{Crescimento do mercado imobiliário e alterações ambientais: desafios para o gerenciamento costeiro}

As paisagens litorâneas do Brasil estão entre aquelas que mais sofreram nos últimos anos o processo de ocupação humana (Vasconcelos, 2005). Tal fato determinou um considerável processo de degradação ambiental, pela crescente pressão sobre os recursos naturais e pela capacidade limitada de esses ecossistemas absorverem os impactos resultantes.

Em Garopaba, não é somente a Lagoa das Capivaras e o seu entorno que sofrem o processo

TABELA 2 - Número de estabelecimentos diretamente relacionados ao turismo abertos no município de Garopaba na década de 1990.

\begin{tabular}{ccc}
\hline Setor & $\mathbf{1 9 9 0}$ a 1995 & $\mathbf{1 9 9 6}$ a 2000 \\
\hline Alojamento e alimentação & 27 & 36 \\
Imobiliário & 8 & 13 \\
Construção civil & 2 & 6 \\
\hline
\end{tabular}

FONTE: Baseado em Guilardi (2014). 
de degradação decorrente do avanço da urbanização e do crescimento do turismo em massa. Exemplos deste processo de degradação ambiental são apontados por Jacomel (2012), referentes à ocupação de áreas úmidas, e por Capelesso \& Cazella (2011), com relação à ocupação do entorno da Lagoa de Garopaba.

O acelerado crescimento econômico e demográfico das cidades litorâneas tem levado ao aumento de uma malha edificada, potencializando o desenvolvimento de extensos contínuos urbanizados. Estes contribuem para a solidificação das áreas metropolitanas e determinam grandes mudanças na paisagem (Silva et al., 2012).

Segundo Araújo (2013, p. 3), "novos espaços e equipamentos urbanos e novos serviços públicos e privados surgiram para fomentar os recreios e a sociabilidade de inspiração da burguesa [...]". A criação desses novos espaços se dá pela "imposição de uma ideologia da felicidade" (Sánchez, 2010, p. 42), derivada do consumo e de um urbanismo moldado para determinadas classes sociais, que está associado à tranquilidade, à suavidade e à beleza de paisagens naturais distantes dos centros urbanos (Silva \& Fonseca, 2010).
O município de Garopaba, conhecido por suas praias e belezas naturais, é visualizado pelo mercado imobiliário como objeto de venda subordinado ao mercado capitalista. Entende-se, neste contexto, a mercantilização de espaços que até então estavam sob o domínio público e que passaram a ser de domínio privado a partir do avanço deste modelo econômico de desenvolvimento (Harvey, 2005; Sánchez, 2010). A transformação das cidades em mercadorias (Carlos, 2015) acentua a disputa pela conquista do espaço (Santos, 1999), que passa a ser exposto para a venda em um mercado internacional (Sánchez, 2001; Vasconcelos \& Coriolano, 2008). Este processo pode ser observado nas propagandas de empreendimentos imobiliários divulgados com o slogan "internacional" (Figura 6).

O espaço natural, apropriado por empreendedores, é anunciado, muitas vezes, como residência "verde", ou seja, como construções ambientalmente corretas. Esse ambiente não é natural, mas construído para saciar as necessidades de uma nova geração de sociedade, que busca a qualidade de vida ao entorno da natureza (Lefèbvre, 1991), o que revela as contradições deste processo. A Figura 7 apresenta a propaganda de venda de dois empreendimentos

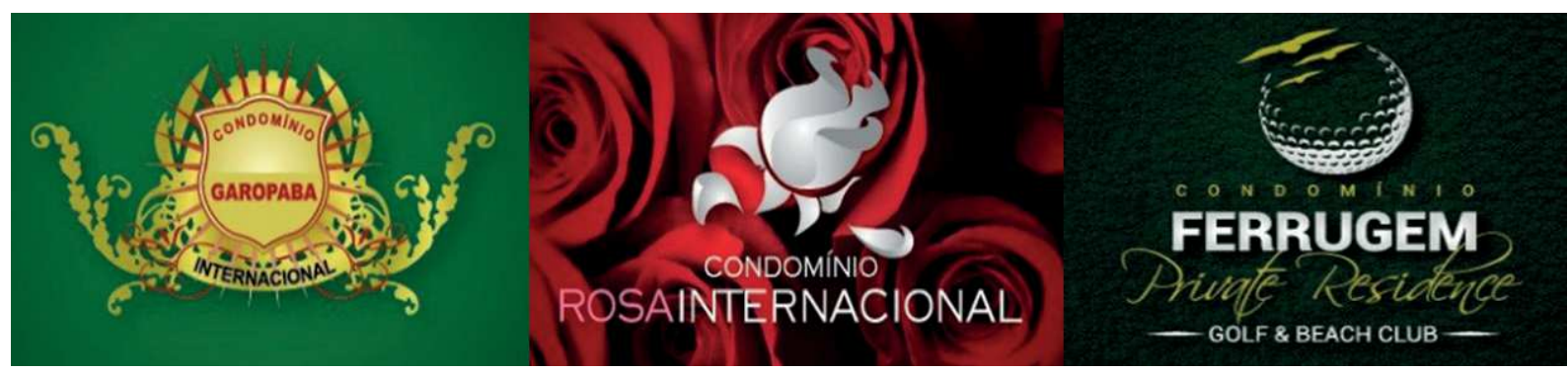

FIGURA 6 - Anúncio de empreendimentos imobiliários em Garopaba.

FONTE: Google, 2017. 
imobiliários em Garopaba. Na primeira imagem, o slogan é "Eco Village Garopaba - Qualidade de vida em sintonia com a natureza". Já a segunda imagem apresenta o seguinte slogan: "Você a poucos passos do mar: natureza, diversão, infraestrutura completa, e... ah claro! sua casa no meio de tudo isso".

Os novos empreendimentos imobiliários persistem em unir sua imagem à da natureza como forma de representar um ambiente tranquilo, saudável e com qualidade de vida para se viver. Deste modo, os componentes do meio ambiente são favorecidos, tendo um novo significado, tornando-se interessantes para o mercado imobiliário ao ponto de representarem a valorização de residências e espaços da cidade, resultando em uma apropriação diferenciada do espaço urbano (Penna, 2002). Assim, o valor do espaço costeiro faz-se proporcional às possibilidades futuras de uso e à capacidade de gerar renda e lucro.

A consolidação do mercado imobiliário e a superconcentração de atividades econômicas exigem um novo modelo de desenvolvimento e gestão do território costeiro brasileiro, que, segundo a legislação, é Patrimônio Nacional (Brasil, 1988). Neste sentido, o conceito de ecodesenvolvimento emerge como uma crítica ao caráter economicista do desenvolvimento, por meio de uma concepção sistêmica que compreende a sustentabilidade a partir da integração de múltiplas dimensões - social, cultural, econômica, ambiental, ecológica, política e espacial (Sachs, 2006). Esta perspectiva abrange a satisfação das necessidades básicas da população, superando a noção de desenvolvimento sustentável. Baseia-se na valorização dos recursos específicos de cada região, concebendo o meio ambiente como patrimônio e bem comum coletivo, e na participação comunitária como condição para a construção gradual do desenvolvimento pautado na equidade social, na economia diversificada e na prudência ecológica (Fontan \& Vieira, 2011).

Mais recentemente, este enfoque vem sendo repensado visando absorver a evolução das pesquisas sobre gestão de recursos comuns. A gestão integrada e compartilhada dos recursos comuns,
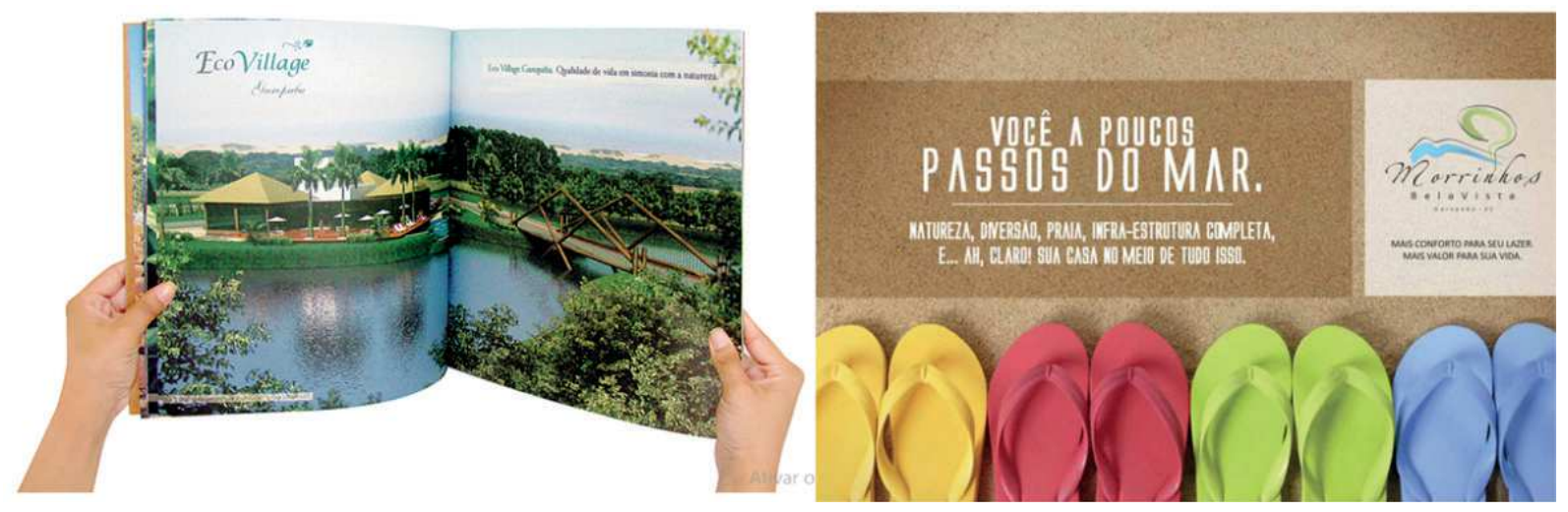

FIGURA 7 - Propaganda de empreendimentos imobiliários em Garopaba. FONTE: Google, 2017. 
ou cogestão adaptativa, constitui atualmente um importante instrumento de construção da cidadania ambiental. No âmbito deste enfoque, torna-se essencial que as comunidades locais passem a compreender cada vez melhor as dinâmicas de ocupação territorial, apropriação e uso dos recursos naturais (Vieira et al., 2010).

Muitos problemas enfrentados pelos municípios litorâneos poderiam ter sido evitados, caso houvessem sido definidos e aplicados critérios e instrumentos de planejamento da ocupação e uso do solo (Scherer et al., 2014; Andrade \& Scherer, 2014). O planejamento de uso e ocupação das áreas costeiras e oceânicas, com respaldo em leis específicas, deve garantir o uso adequado ou recomendável para cada local e a proteção da biodiversidade dos ecossistemas. A deficiência no gerenciamento costeiro no Brasil é resultado do processo histórico de organização político-administrativa territorial e da consequente abundância de instituições, processos, normas e controles de diversas esferas, sem um diálogo efetivo entre elas. No entanto, a gestão deste espaço pode ser adequada para reverter as inúmeras dificuldades presentes na zona costeira (Polette \& Silva, 2003), assegurando o uso adequado de áreas públicas e a segurança para a população e os ecossistemas frente a eventos de ordem antrópica ou natural (Marroni \& Asmus, 2005). Para tanto, é necessário um plano de gestão integrado, que leve em consideração as diretrizes dos demais instrumentos de planejamento e gestão existentes na escala da Zona Costeira, como, por exemplo, o Plano Diretor Municipal (PDM).

A ocupação do solo é um ponto crítico em vários pontos da cidade de Garopaba, existindo um parcelamento sem critérios, que é condutor de inúmeros conflitos na área (Jacomel, 2012). Re- centemente, a prefeitura realizou uma intervenção na área do entorno da lagoa das Capivaras com o objetivo de iniciar o processo de recuperação do local, pois, segundo o Plano Diretor e as escrituras dos terrenos do entorno, a Lagoa das Capivaras já não existiria mais (Garopaba, 2008). Ou seja, nos documentos do órgão municipal, a área da lagoa seria um terreno disponível para uso. Segundo um funcionário da prefeitura ouvido pela pesquisa, isso se deve ao fato de estes terrenos terem sido repassados para terceiros na forma de herança familiar, mas que seriam propriedades que estão ainda em processo de inventário e desmembramento.

É importante destacar que o Plano Diretor Municipal - PDM - é um instrumento de planejamento e gestão considerado extremamente importante para a gestão municipal (Rezende \& Ultramari, 2007), podendo contribuir para a construção de cidades com uma maior qualidade de vida para todos. Sua elaboração deve ocorrer por meio de mecanismos democráticos, que viabilizem a prática da gestão compartilhada e integrada, com a participação da comunidade no planejamento urbano (Moreira, 2008).

Por meio dos relatos dos moradores e do órgão municipal, pode-se perceber que a participação da população local é bastante restrita na construção do PDM. A maioria dos entrevistados afirmou não participar das reuniões sobre o plano diretor; alguns disseram não saber o que era o plano diretor.

Aqueles que afirmaram não participar das reuniões relataram não saber destes encontros. Os entrevistados que afirmaram ter conhecimento a respeito do plano diretor do município ressaltaram que a maioria das pessoas que participava das reuniões eram empresários do município e funcionários da prefeitura e que a população local não se 
fazia presente, ressaltando que eram raras as vezes quando havia a participação de algum morador mais antigo. Estes dados sugerem que, ainda que sejam realizadas audiências públicas pelo poder municipal, ainda se faz necessário efetivar a participação da população local de forma a garantir não apenas sua presença, mas sua atuação de forma democrática na elaboração destes instrumentos de gestão e planejamento urbano. Esta efetivação da participação popular exige o reconhecimento das assimetrias de poder entre os atores sociais envolvidos e o desenvolvimento de estratégias para superá-las (Souza, 2006).

Na busca de alternativas para a reversão dos processos de degradação ambiental, foi proposto pela ONG (Organização Não Governamental) Associação Comunitária Amigos do Meio Ambiente (AMA) e pelo Parque Científico e Tecnológico (IPARQUE), da Universidade do Extremo Sul Catarinense (UNESC), um Plano de Recuperação de Área Degradada (PRAD) para a Lagoa das Capivaras, como forma de reparação dos danos ambientais que foram objeto da Ação Civil Pública mencionada anteriormente. Esta proposição foi primeiramente apresentada no laudo pericial no contexto do processo de liquidação de sentença. Trata-se de uma série de programas e ações que permitem reverter o atual processo de degradação desta lagoa, visando ao seu retorno a uma condição de equilíbrio ecológico.

O projeto propõe, como forma de reversão do atual estado de degradação, que a lagoa seja transformada em um parque ecológico municipal, possibilitando a preservação da área do seu entorno, com a adoção de medidas de recuperação ambiental e revitalização da área ocupada atualmente pela lâmina d'água. Este espaço transformado em uma unidade de proteção integral possibilitaria apenas o seu uso indireto para atividades de visitação e educação ambiental, constituindo-se, desta forma, em um novo atrativo para turistas e moradores.

Os sujeitos da pesquisa entendem que o primeiro passo a ser dado para a recuperação e a revitalização da lagoa seria a retirada das plantas aguapés - no entorno, denominando-a como uma "limpeza" que contribuiria para que a lagoa voltasse ao seu tamanho original, já que o crescimento destas plantas aquáticas teria ocasionado a diminuição de sua extensão. Durante a pesquisa de campo, foram observadas duas "limpezas" realizadas pelo órgão municipal na Lagoa das Capivaras, que implicaram o corte e a queima de árvores e plantas nativas (Figura 8), o que tem gerado conflitos entre a sociedade civil organizada e a prefeitura. Após a última "limpeza", atores de um movimento ambientalista local acusaram a prefeitura de ter cometido um crime ambiental, por ter suprimido vegetação nativa de restinga. Além disso, segundo a ONG, a prefeitura teria realizado a ação sem assessoramento técnico e utilizado areia de dunas para aterrar o local, o que teria provocado danos a uma Área de Preservação Permanente - APP (AMA, 2017). A prefeitura, por meio de nota de esclarecimento emitida juntamente com a Secretaria de Agricultura e Pesca do município, defendeu a ação, caracterizando-a como fundamental para a preservação da área por ter removido vegetação exótica invasora (aguapés), além de citar outras medidas para a posterior criação de um Parque Ecológico Municipal no local (Garopaba, 2017).

Estes processos de alterações ambientais podem originar uma fase de estagnação e possível declínio do ponto de vista ecológico (Polette et al., 2000), acarretando uma mudança do espaço, ou, até mesmo, a degradação ou o desaparecimento de áreas 
naturais. Polette et al. (2000) presumem um modelo de ciclo de evolução para áreas de grande potencial turístico, a partir do modelo desenvolvido por Butler (1980). Os autores explicam que, inicialmente, haverá um número pequeno de visitantes em razão das dificuldades de acesso; as facilidades de acesso serão reformuladas, dando suporte e estrutura para a vinda de novos visitantes e residentes. Posteriormente, com a divulgação do local, a área irá criar renome e rapidamente crescerá. Consequentemente, com o crescimento demográfico, a capacidade de suporte do local entrará no seu limite e, progressivamente, em declínio.

Este processo pode ser observado por meio de alguns fatores, como a falta de água, a diminuição da qualidade do ar e da água, o transporte inadequado ou a ausência de transporte coletivo, a falta de saneamento básico, entre outros. Deste modo, a área deixará de ser um atrativo, tendo em vista seu intenso uso e o impacto causado pelo turismo, como, por exemplo, acúmulo de lixo, esgoto, barulho excessivo, havendo grande propensão de eversão, ou seja, destruição da zona costeira (Polette et al., 2000). Estudos realizados em diferentes municípios litorâneos do Brasil corroboram esta relação entre processo acelerado de urbanização, turistificação, degradação ambiental e mudanças espaciais (Souza et al., 2006; Correa \& Dantas, 2013; Luna, 2014).

Não é somente o turismo de massa que pode levar ao declínio da área, mas também as atividades

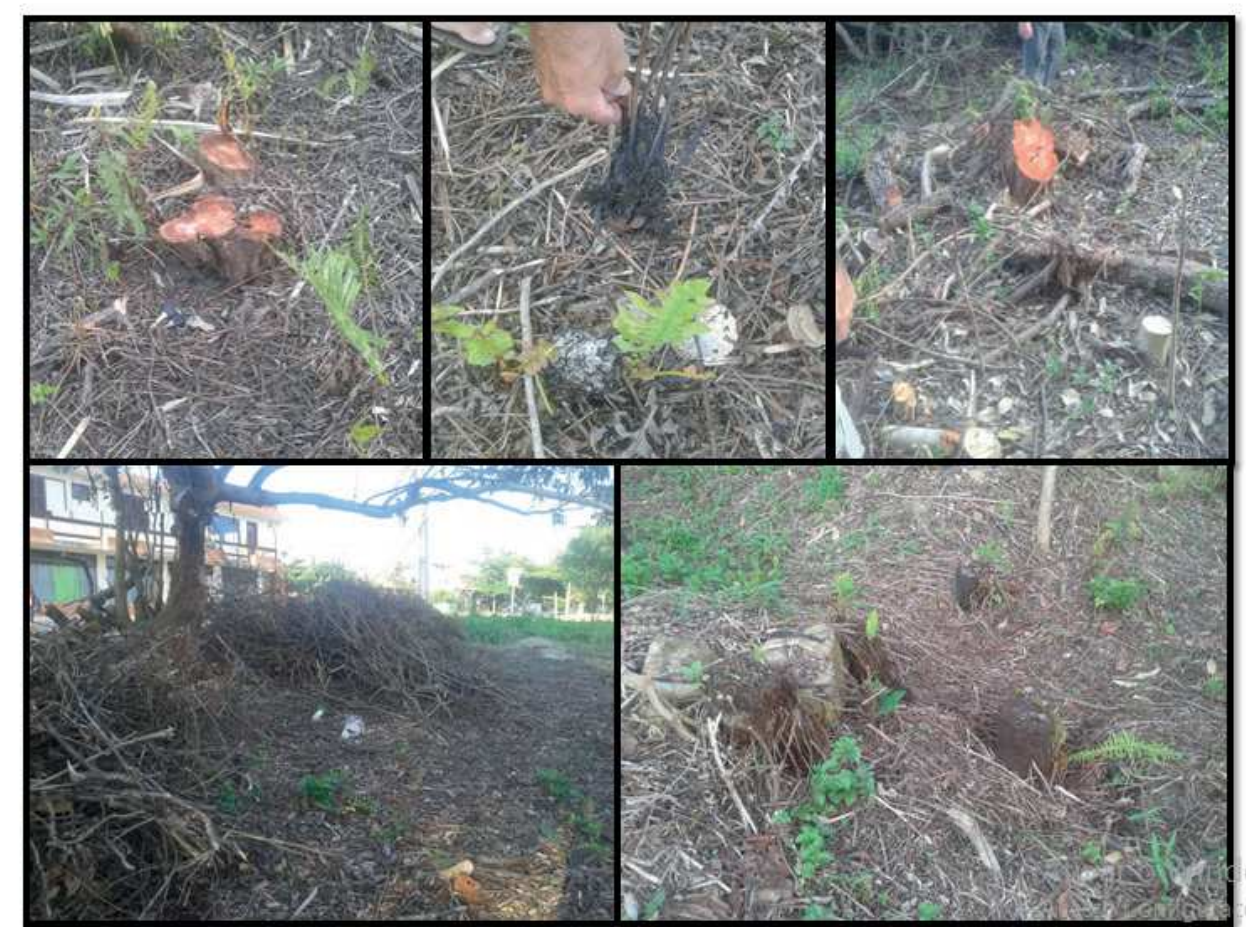

FIGURA 8 - Entorno da lagoa após "limpeza" do órgão municipal.

FONTE: Fotos de Munari, 2016. 
industriais predatórias. Indústrias estão se instalando no local, consolidando atividades econômicas destinadas a atender a população mundial, como a pesca industrial (Capellesso \& Cazella, 2011). Segundo os sujeitos da pesquisa, a chegada de barcos pesqueiros industriais na região acarretou um declínio da pesca artesanal no município. Os pescadores locais apontaram a falta de fiscalização como principal problema.

\section{Considerações finais}

Por meio desta pesquisa, que objetivou compreender os processos de mudança e transformação da Lagoa das Capivaras e de seu entorno com base na memória de moradores locais, foi possível demonstrar que estas alterações devem ser analisadas considerando-se os processos de urbanização e de crescimento da atividade turística em Garopaba. Ainda que o turismo seja promotor de crescimento econômico no município, no contexto em que vem sendo realizado, ele também consiste em um fator de degradação socioambiental. Os ecossistemas locais vêm sendo degradados por ações do mercado imobiliário, que compreende o ambiente como um conjunto de bens utilizáveis, não considerando sua capacidade de suporte e resiliência.

Nesse contexto, impõe-se cada vez mais a busca de alternativas ao modelo dominante de desenvolvimento e gestão. Os pressupostos contidos no conceito de ecodesenvolvimento mostram-se como um novo meio de desenvolvimento do território que não possui como enfoque central apenas o desenvolvimento econômico, mas busca inserir uma concepção social e ambiental, bem como uma participação comunitária para o planejamento das ações para o desenvolvimento, evidenciando ainda mais as potencialidades de cada região e seu fortalecimento (Sachs, 2006; Vieira, 2016).

Este novo modelo de desenvolvimento também implica repensar a concepção de turismo para a zona costeira. Como afirmam Vasconcelos \& Coriolano (2008, p. 271), o modelo de turismo globalizado, voltado aos megaempreendimentos, foi trazido aos denominados países "em desenvolvimento", mas "não ofereceu oportunidades e vantagens às comunidades receptoras por não incluí-las em seus projetos". Em contraposição a este modelo, faz-se necessário construir alternativas locais com base na sustentabilidade socioambiental e em valores humanos e culturais, fundadas em uma nova perspectiva do lugar e do turismo. Esta concepção deve possibilitar a promoção de um turismo que não é apenas voltado ao consumo, mas que também proporcione trocas de experiências, a formação de laços de amizade e a valorização da cultura local (Vasconcelos \& Coriolano, 2008).

As alterações urbanístico-turísticas sobre a zona costeira despontam como um processo altamente impactante no ordenamento territorial ambiental, acarretando retrocessos na conservação ambiental, despertando para a necessidade de incorporação de novas concepções ao planejamento e à gestão do espaço costeiro pautadas em instrumentos legais existentes (Corrêa \& Fontenelle, 2010). Por meio de um planejamento espacial costeiro, concebido de forma integrada e participativa, é possível fazer com que essa mudança na paisagem apresente uma maior harmonia com a natureza e com as próprias pessoas que residem no local há muito mais tempo (Freitas et al., 2012).

A pesquisa apresentada, caracterizada como um estudo de caso, buscou contribuir para a com- 
preensão das alterações socioambientais ocorridas em um município da zona costeira brasileira, ciente de que os problemas aqui expostos configuram a realidade de muitos outros contextos do litoral do país. Diante do exposto, na perspectiva de evitar o agravamento dos impactos existentes, bem como o surgimento de novos conflitos, torna-se necessária a introdução de ações que considerem os aspectos físicos e sociais locais. Sugerem-se, então, intervenções, por parte dos órgãos públicos responsáveis pelo gerenciamento da zona costeira, fazendo cumprir as exigências ambientais vigentes.

\section{Referências}

AMA - Associação Comunitária Amigos do Meio Ambiente. AMA emite nota sobre limpeza na Lagoa das Capivaras. Notícias em Foco. Disponível em: <https://www.noticiasinfoco.com.br/artigo/ama-emite-nota-sobre-limpeza-da-lagoa-das-capivaras>. Acesso em: 9 nov. 2017.

Andrade, J.; Scherer, M. E. G. Decálogo da gestão costeira para Santa Catarina: avaliando a estrutura estadual para o desenvolvimento do Programa Estadual de Gerenciamento Costeiro. Desenvolvimento e Meio Ambiente, 29, 139-154, 2014. Disponível em: $<$ http://revistas.ufpr.br/made/article/ viewFile/31405/22442>.

Araújo, G. P. Trajetória do turismo no litoral Centro Sul de $S C$ : impactos socioambientais, desafios e oportunidades para estratégias de desenvolvimento territorial sustentável. Florianópolis, Dissertação (Mestrado em Agroecossistemas) - UFSC, 2008.

Araújo, R. C. B. A cultura da praia: urbanização, sociabilidade e lazer no Brasil, 1840-1940. In: Acta Cientifica do XXIX Congreso de la Asociación Latinoamericana de Sociología, 2013. p. 1-8.

Asmus, M. L.; Kitzmann, D.; Laydner, C.; Tagliani, C. R. A. Gestão Costeira no Brasil: Instrumentos, fragilidades e potencialidades. Gerenciamento Costeiro Integrado, 4,
52-57, 2006.

Bataller, M. A. S. O estudo da gentrificação. Revista Continentes, 1, 9-37, 2012.

Bauer, M. W. Entrevistas individuais e grupais. In: Bauer, M. W.; Gaskell, G. (Orgs.). Pesquisa qualitativa com texto, imagem e som: um manual prático. Petrópolis, Rio de Janeiro: Vozes, 2008. p. 64-89.

Bauer, M. W.; Gaskell, G.; Allum, N. C. Qualidade, quantidade e interesses do conhecimento: evitando confusões. In: Bauer, M. W.; Gaskell, G. (Orgs.). Pesquisa qualitativa com texto, imagem e som: um manual prático. Petrópolis, Rio de Janeiro: Vozes, 2008. p. 17-36.

Becker, B. K. Levantamento e avaliação da política federal de turismo e seu impacto na região costeira. Brasília: Ministério do Meio Ambiente, dos Recursos Hídricos e da Amazônia Legal, 1995.

Bidou-Zachariasen, C. Introdução. In: Bidou-Zachariasen, C. (Org.). De volta à cidade: dos processos de gentrificação às políticas de "revitalização" dos centros urbanos. São Paulo: Annablume, 2006. p. 21-57.

Bosi, E. Memória e sociedade: lembranças de velhos. São Paulo: Companhia das Letras, 1979.

Brasil. Constituição da República Federativa do Brasil, de 5 de outubro de 1988. Brasília: Senado Federal: Centro Gráfico, 1988.

Brasil. Conselho Nacional de Saúde. Resolução n. 466, de 12 de dezembro de 2012. Brasília, 2012. Disponível em: $<$ http://conselho.saude.gov.br/resolucoes/2012/Reso466. pdf $>$. Acesso em: dez. 2016.

Butler, R. W. The Concept of a Tourist Area Cycle of Evolution: Implications for Management of Resources. Canadian Geographer, 24, 5-12, 1980. doi: 10.1111/j.1541-0064.1980. tb00970.x

Capelesso, A. J.; Cazella, A. A. Pesca artesanal entre crise econômica e problemas socioambientais: estudo de caso nos municípios de Garopaba e Imbituba (SC). Ambiente \& Sociedade, 14, 15-33, 2011. doi: 10.1590/S1414753X2011000200003

Carlos, A. F. A. A virada espacial. Mercator, 14(4), 7-16, 


\section{5. doi: 10.4215/RM2015.1404. 0001}

Cerdan, C.; Freire Vieira, P.; Policarpo, M.; Vivacqua, M.; Capellesso, A.; Castro Rodrigues, H.; Martinel, B.; Cordeiro, E.; Lesage, A.; Meynard, F.; Pedrosa, A.; Adriano, J.; Leonel, M.; Ferreira, M. A. Desenvolvimento territorial sustentável na zona costeira do Estado de Santa Catarina Brasil. 2011. Documento de Trabajo N 87. Programa Dinámicas Territoriales Rurales. Rimisp, Santiago, Chile. Disponível em: <http://www.rimisp.org/wp-content/ files_mf/1378402235CerdanFreireVieiraPolicarpoetalDesenvolvimentoterritorialzonacosteiraSantaCatarina.pdf $>$. Acesso em: maio 2015.

Cerqueira, E. D. V. A evolução das formas de gentrificação: estratégias comerciais locais e o contexto parisiense. Caderno Metropolitano, 16, 417-436, 2014. doi: 10.1590/22369996.2014-3206

Comerlato, F. As armações baleeiras na configuração da costa catarinense em tempos coloniais. Tempos Históricos, 15, 481-501, 2011.

Correa, M. L. A.; Dantas, E. W. C. Campos de dunas na praia do futuro: contribuição da legislação na produção de políticas públicas no litoral fortalezense. In: Anais do III ENECS - Encontro Nacional sobre Edificações e Comunidades Sustentáveis. São Carlos - SP, 21-24 out. 2013.

Corrêa, W. B., Fontenelle, T. H. Processo de ocupação da zona costeira: Ecoresorts e Gerenciamento Costeiro do Meso Compartimento Cabo Frio - Cabo Búzios, Litoral do Rio de Janeiro. In: Anais do XVI Encontro Nacional dos Geógrafos. Porto Alegre, 25 jul., 2010.

Esteves, F. A. Fundamentos de Limnologia. Rio de janeiro: Interciência, $2011.575 \mathrm{p}$.

Filardi, A. C. L. Diagnóstico da Pesca Artesanal Marinha do Municipio de Garopaba (SC): potencialidades e obstáculos para a gestão adaptativa para o ecodesenvolvimento. Florianópolis, Dissertação (Mestrado em Geografia) UFSC, 2007.

Fontan, J. M.; Vieira, P. F. Por um enfoque sistêmico, ecológico e "territorializado". In: Tremblay, G.; Vieira, P. F. (Orgs.). O papel das universidades no desenvolvimento local: experiências brasileiras e canadenses. Florianópolis: Ed. APED; Secco, 2011. p. 19-80.
Freitas, M. D.; Delgado, R. C.; Rodrigues, R. A.; Souza, L. P.; Variabilidade espaçotemporal na mudança da paisagem no município de Acrelândia, AC. Enciclopédia Biosfera, 8(14), 2012.

Garopaba. Prefeitura Municipal de Garopaba. Plano Diretor Municipal: levantamentos da fase inicial. Execução Consórcio HardtEngemin. Supervisão Companhia de desenvolvimento de Santa Catarina (CODESC), 2008.

Garopaba. Prefeitura Municipal de Garopaba. Disponível em: <http://www.garopaba.sc.gov.br/>. 2016.

Garopaba. Nota de esclarecimento sobre a Lagoa das Capivaras. Garopaba Midia. Disponível em:<http://www. garopabamidia.com.br/noticias/titulo/9321/nota-de-esclarecimento-sobre-a-lagoa-das-capivaras $>$. Acesso em: 9 nov 2017.

Gaskell, G. Entrevistas individuais e grupais. In: Bauer, M. W.; Gaskell, G. (Orgs.). Pesquisa qualitativa com texto, imagem e som: um manual prático. 13. ed. Petropolis, Rio de Janeiro: Vozes, 2008. p. 64-89.

Gomes, R. A análise de dados em pesquisa qualitativa. In: Deslandes, S. F.; Cruz Neto, O.; Gomes, R. (Orgs.). Pesquisa social: teoria, método e criatividade. Petrópolis, Rio de Janeiro: Vozes, 2000. p. 67-79.

Guilardi, L. Garopaba (SC): economia colonial, complexo rural e acumulação flexível do capital. Florianópolis, Dissertação (Mestrado em Geografia) - UFSC, 2014.

Halbwachs, M. A memória coletiva. São Paulo: Centauro, 1990.

Hamnett, C. The blind men and the elephant: the explanation of gentrification. Transactions of the Institute of British Geographers, New Series, 16(2), 173-189, 1991.

Harvey, D. A produção capitalista do espaço. São Paulo: Annablume, 2005.

IBGE - Instituto Brasileiro de Geografia e Estatística. Cidades, 2010.

Jacomel, F. Conflitos socioambientais em áreas úmidas na zona costeira catarinense: estudo de caso relacionado à ocupação predatória do Banhado da Palhocinha, no Município de Garopaba, no período de 1998 a 2012. Florianópolis, Dis- 
sertação (Mestrado em Sociologia Política) - UFSC, 2012. Jerônimo, R. N.; Gonçalves, M. T. Identidade e personificação do lugar na apropriação do espaço pelos nativos de Ibiraquera, SC. Revista de Ciências Humanas, 47, 117-132, 2013. doi: 10.5007/2178-4582.2013v47n1p117

Kjerfve, B. Coastal lagoons processes. Amsterdan: Elsevier, 1994.

Kohara, L.; Uemura, M.; Ferro, M. C. Moradia é central: lutas, desafios e estratégias. São Paulo: Centro Gaspar Garcia de Direitos Humanos, 2012.

Lefebvre, H. The production of space. Trans. by Donald Nicholson-Smith. Oxford: Blackwell, 1991. (Trans. of $L a$ Production del'espace. Paris: Anthropos, 1974).

Lojkine, J. O estado capitalista e a questão urbana. São Paulo: Martins Fontes, 1997.

Luna, G. A. G. "Não deixe o Canto do Morcego acabar": embates entre preservacionistas e investidores na Praia Brava - Itajaí (SC). Fronteira: Revista Catarinense de História, 24, 115-134, 2014. Disponível em: <http://www. anpuh-sc.org.br/rev\%20front $\% 2024 \% 20$ vers\%20fin/f24-artrev1-gloria_luna.pdf>.

Machado, H. C. F. A construção social da praia. Cadernos do Nordeste, 13, 201-218, 2000.

Mariano, N. M. Diagnóstico ambiental como subsídio para recuperação de lagoas costeiras: estudo de caso da Lagoa das Capivaras - Garopaba - SC. Criciúma, Dissertação (Mestrado em Ciências Ambientais) - UNESC, 2010.

Marroni, E. V.; Asmus, M. L. Gerenciamento Costeiro: uma proposta para o fortalecimento comunitário na gestão ambiental. Pelotas: USEB, 2005.

Matos, E. A. C.; Gruber, N. L. S. Os efeitos da atividade turística no litoral norte do Rio Grande Do Sul. Revista Eletrônica Para Onde?, 3, 1-17, 2012. Disponível em: <http:// seer.ufrgs.br/paraonde/article/view/22102>.

Menezes, C. T. B. de M.; Damásio, M. Educação Ambiental e Gestão de Ambientes Costeiros no município de Garopaba, Santa Catarina. Criciúma: Programa de Iniciação Cientifica (PIC V) - Relatório Final, 2005.

Moreira, H. F. O plano diretor e as funções sociais da ci- dade. Serviço Geológico do Brasil-CPRM. Rio de Janeiro, 2008. Disponível em: <http://www.cprm.gov.br/publique/ media/plano_diretor_helion.pdf $>$. Acesso em: out. 2016.

Neto, C. M. Turismo e urbanização: os problemas ambientais da Lagoa de Araruama - Rio de Janeiro. Ambiente \& Sociedade, 19, 4-19, 2016. doi: 10.1590/1809-4422asoc137111v1942016

Penna, N. A. Urbanização, cidade e meio ambiente. GEOUSP - Espaço e Tempo, 12, 1-10, 2002. Disponível em: $<$ http://www.geografia.fflch.usp.br/publicacoes/Geousp/ Geousp12/Geousp12_NelbaPenna.htm>.

Pereira, H. da F. A.; Eston, M. R. de. Biologia e manejo de capivaras (Hydrochoerus hydrochaeris) no Parque Estadual Alberto Löfgren. Revista Instituto Florestal, 19, 55-64, 2007.

Pires, C. Â. O fenômeno da favelização no interior de Minas Gerais: o desafio das políticas públicas no direito à moradia. Perspectivas em Políticas Públicas, 4, 145-167, 2016. Disponível em: <http://revista.uemg.br/index.php/ revistappp/article/view/1009>.

Polette, M. Diehl, F. L.; Diehl, F. P.; Sperb, R. M.; Schettini, C. A. F.; Klein, A. H. F.; Gerenciamento Costeiro Integrado e Gerenciamento de Recursos Hídricos: como compatibilizar tal desafio. In: Muñoz, H. R. Interface da Gestão de Recursos Hídricos: Gestão de Bacias e Gestão de Zonas Costeiras. Brasília: Secretaria de Recursos Hídricos, 2000. p. 221-239.

Polette, M.; Silva, L. P. Gesamp, Icamp e PNGC - Análise comparativa entre as Metodologias de Gerenciamento Costeiro Integrado. Revista da Sociedade Brasileira para o Progresso da Ciência, 4, 55-66, 2003. Disponível em: <http:// cienciaecultura.bvs.br/pdf/cic/v55n4/a17v55n4.pdf>.

Reis, G. M. P. A alteração dos limites do Parque Estadual da Serra do Tabuleiro diante do dever fundamental de proteção ambiental. Associação dos Juízes Federais de Santa Catarina - AJUFESC, 2012.

Rezende, D. A.; Ultramari, C. Plano diretor e planejamento estratégico municipal: introdução teórico-conceitual. Revista de Administração Pública, 41, 255-271, 2007. doi: 10.1590/S0034-76122007000200005

Ribeiro, M. A.; Coura, M. F. A importância da gestão inte- 
grada costeira e marinha no controle de impactos socioambientais e seus aportes para o fomento do desenvolvimento sustentável no Brasil. In: Vieira, P. F. (Org.). Conservação da diversidade biológica e cultural em zonas costeiras: enfoques e experiências na América Latina. Florianópolis: APED, 2003. 528 p., p. 265-269.

Rodrigues, L. C. Turismo em espaços urbanos: processos de turistificação no Nordeste brasileiro e no Caribe Mexicano. Revista Iberoamericana de Turismo, 5, 81-104, 2015.

Sachs, I. Rumo à ecossocioeconomia. Teoria e prática do desenvolvimento. Paulo Freire Vieira (Org.). São Paulo: Cortez Editora, 2006.

Sampaio, C. A. C. Sociologia do turismo: implicações da atividade turística como fenômeno humano. Revista de Divulgação Cultural, 25, 88-92, 2003.

Sánchez, F. A reinvenção das cidades na virada de século: agentes, estratégias e escalas de ação política. Revista Sociologia Política, 2001, 16, 31-49, 2001. Disponível em: $<$ http://revistas.ufpr.br/rsp/article/view/3584>.

Sánchez, F. A reinvenção das cidades para um mercado mundial. Chapecó: Argos, 2010.

Santin, L. O papel dos sistemas locais de conhecimento agroecologico no desenvolvimento territorial sustentável: Estudo de caso junto a agricultores familiares no litoral centro-sul do Estado de Santa Catarina. Florianópolis, Dissertação (Mestrado em Agroecossistemas) - UFSC, 2005.

Santos, C. J. F. Várzea do Carmo: lavadeiras, caipiras e "pretos veios". Memória Energia, São Paulo: Fundação Patrimônio Histórico da Energia de São Paulo, 28, 74-96, 2001.

Santos, M. A urbanização brasileira. São Paulo: Hucitec, 1993.

Santos, M. A natureza do espaço: espaço e tempo; razão e emoção. São Paulo: Hucitec, 1999.

Santos, M. O espaço do cidadão. São Paulo: EdUSP, 2007.

Santos, S. C. Nova história de Santa Catarina. Florianópolis: Editora da UFSC, 2004.

Scarpeline, R. Lugar de morada versus lugar de memória: a construção museológica de uma Casa Museu. Revista Musear, 2, 77-91, 2012.
Scherer, M.; Andrade, J. ; Emerim, E.G. ; Felix, A. ; Oliveira, T.C.R. ; Mondl, H.B. ; Lima, F.A. Veiga . Prioritizing actions for coastal management: A methodological proposal. Ocean \& Coastal Management, 91, 17-22, 2014. doi: 10.1016/j. ocecoaman.2014.01.012

Silva, F. B.; Marques, T. S.; Delgado, C. Processos de expansão urbana e mudanças na paisagem: ensaio metodológico (1950-2000). Revista da Faculdade de Letras - Geografia, 1, 161-183, 2012. Disponível em: <http://ler.letras.up.pt/ uploads/ficheiros/10561.pdf>.

Silva, K. O.; Fonseca, M. A. P. A produção de residência secundária no litoral oriental Potiguar - Turismo e capital imobiliário. Caderno Virtual de Turismo, 10, 50-63, 2010.

Silva, O. T. A valorização da terra e a especulação imobiliária: as transformações do mercado de terras urbanas em Niterói, São Gonçalo, Itaboraí e Maricá na nova conjuntura de produção flexível. Revista Tamoios, 1, 1-19, 2008. Disponível em: <http://www.e-publicacoes.uerj.br/index.php/ tamoios/article/view/656/690>.

Simmel, G. Questões fundamentais de sociologia: indivíduo e sociedade. Tradutor: Pedro Caldas. Rio de Janeiro: Zahar, 2006.

Smith, N. Gentrificação, a fronteira e a reestruturação do espaço urbano. GEOUSP - Espaço e Tempo, 21, 15-31, 2007. Disponível em: <http://www.geografia.fflch.usp.br/ publicacoes/Geousp/Geousp21/Artigo_Neil.pdf>.

Souza, M. L. A prisão e a ágora: reflexões em torno da democratização do planejamento e gestão das cidades. Rio de Janeiro: Bertrand Brasil, 2006.

Souza, S. do R. de; Bahl, M.; Kushano, E. S. O espaço do turismo: produção, apropriação e transformação do espaço social. Revista Hospitalidade, 2, 313-331, 2013. Disponível em: <https://www.revhosp.org/hospitalidade/article/ viewFile/531/546>.

Souza, U. Pereira, M. R. O.; Ferreira, L.M.R.M.; Silva, A.F.G.; Feitosa, A.C. Caracterização geomorfológica na costeira de Panaquatira, município de São José de Ribamar-MA. In: Anais - VI Regional Conference on Geomorphology. Goiânia, 10 ago. 2006.

Tuan, Y. Topofilia: um estudo da percepção, atitudes e va- 
lores do meio ambiente. São Paulo: Difel, 1980.

Un-Habitat's'. State of the World's Cities Report 2016. United Nations Human Settlements Programme. Nairobi: Gutenberg Press. Disponível em: <http://nua.unhabitat. org/uploads/WCRFullReport2016_EN.pdf>. Acesso em: jan. 2017.

Valentim, M. História de Garopaba. Garopaba: Prefeitura Municipal de Garopaba, 2007.

Vasconcelos, F. P. Gestão Integrada da Zona Costeira: ocupação antrópica desordenada, erosão, assoreamento e poluição ambiental do litoral. Fortaleza: Premius, 2005.

Vasconcelos, F. P.; Coriolano, L. N. M. T. Impactos socioambientais no litoral: um foco no turismo e na Gestão Integrada da Zona Costeira no Estado do Ceará/Brasil. Revista da Gestão Costeira Integrada, 8(2), 259-275, 2008. doi: $10.5894 /$ rgci134

Vieira, J. A. O uso do diário em pesquisa qualitativa. Cadernos de Linguagem e Sociedade, 5, 93-104, 2001. Disponível em: http://seer.bce.unb.br/index.php/les/article/ view/1348/1003
Vieira, P. H. F. Ecodesenvolvimento: desvelando novas formas de resistência no Antropoceno. In: Souza, C.; Sampaio, C. A.; Alves, A. R.; Alcântara, L. C. S. (Orgs.). Novos talentos: processos de educação para o ecodesenvolvimento. Blumenau: Nova Letra Editora, 2016. p. 23-63.

Vieira, P. H. F. Cazella, A.; Cerdan, C.; Carrière, J. P.; Desenvolvimento territorial sustentável no Brasil: subsídios para uma política de fomento. Florianópolis: APED; Secco, 2010.

Vinuto, J. A amostragem em bola de neve na pesquisa qualitativa: um debate em aberto. Temáticas, 22, 203-220, 2014. Disponível em: <https://www.ifch.unicamp.br/ojs/ index.php/tematicas/article/view/2144>.

Woortmann, E. F. Identidades e memória entre teuto-brasileiros: os dois lados do Atlântico. Horizonte Antropológico, Porto Alegre, 6(14), 205-238, 2000. doi: 10.1590/S010471832000001400009

Wendel, H. Florianópolis-Brasil - A felicidade não tem preço, tem endereço: condomínios, loteamentos e a apropriação da natureza. Revista Eletronica de Geografía y Ciencias Sociales, 9, 1-14, 2005. Disponível em: <http:// www.ub.edu/geocrit/sn/sn-194-14.htm>. 